\title{
Attendance and Gender Relations on Grades and Other Aspects*
}

Andy Chung, Graham Harding, Joonhong Kim, Koot van Wyk

Department of Liberal Education, Kyungpook National University, Sangju Campus, South Korea

Email: kootvanwyk@gmail.com

How to cite this paper: Chung, A., Harding, G., Kim, J., \& Wyk, K. (2018). Attendance and Gender Relations on Grades and Other Aspects. International Journal of Language Teaching and Education, 2(3).346-372 https://doi.org/10.22437/ijolte.v2i3.5907

Accepted: October 18, 2018

Published: November 30, 2018

Copyright (C) International Journal of Language Teaching and Education. This work is licensed under the Creative Commons Attribution International License (CC BY 4.0).

http://creativecommons.org/licenses/by/4 $\underline{0 /}$

\section{Abstract}

Three aspects prompted this study: why are females in first year university in a countryside campus performing better than males as opposed to high school where the reverse is the case? Why are there waves of performance increases semester by semester? Why is there in the second semester always an increase in performance over the first semester? For this matter the researchers took a number of participants in total over the period 2012-2016, namely 3,963 students in Freshman English at a countryside campus (Sangju) for Kyungpook National University as their target. In the year 2016, only the first semester was calculated in this research. Three aspects were considered as far as data is concerned: attendance variables, grade variables and gender. Performances were always better in the second semester over the first and females almost always outperformed the males. What also came up as secondary considerations, are questions whether the environment like nature and the role of 'table-talk' of parents reverberating or not the GDP of the country over the period may have had an effect on the students. It was found when the GDP went up the students' performance took a break but when the GDP is low the students increased their focus and performed better as their grades indicated. These last aspects were just mere observations and should be carried out with further investigation elsewhere. The attendance of females was always showing better attendance results than males for Freshmen at Sangju Campus, South Korea. While the GDP dropped and rose through the years investigated, the attendance of the students did not display a serious rise and fall but remained almost unchanged.

Subject Areas

${ }^{*}$ Cognitive Linguistics, Comparative Historical Linguistics, Education, Computer Technology, English Literature but all in the same ESL teaching environment

\section{Keywords}

Gender, Grades, Attendance, Motivation, ESL 


\section{Introduction}

Showing up in class may have an influence on the performance of the students academically and the studies on the aspect of attendance and its relation to grades have been the study over decades by many scholars. There are the romanticists who hold fast to a definitive relationship proven to be brighter should the student attend faithfully. There are also the skeptics who indicate that attendance does not automatically mean an increase in performance. The reality is that attendance accompanied by other factors can lead to good performance. So clinically the isolation of attendance and grades as a measure to evaluate is too meager an option to arrive at a true picture of this complex interrelated phenomenon in education. Many factors cut into this ESL event that can affect the students, males and females as a whole and also the same as separate components. Scholars have studied the role of uniform wearing; [1] smoking; [2] sleep (too little or too much); [3] exercise; [4] expectations of the teaching moment; [5] wellness; [6] campus couples and campus dating; [7] diet; [8] assigned seating; [9] compulsory policies or absence thereof; [10] depression and popularity; [11] substances; [12] stress and coping with it, illness and social interaction; [13] alcohol; [14] humor; [15] financial support; [16] "undecided classification;" [17] appraisal; [18] discretion; [19] peer-effect; [20] anxiety; [21] friends; [22] environment; [23] study time and time planning; [24] learning styles; [25] adjustment; [26] mandatory attendance; [27] single sex and mixed sex classes; [28] gender; [29] persistence or retention behavior; [30] attrition; [31] motivation; [32] creative thinking; [33] major choices; [34] adaption, transition and coping; [35] and LGBTQ attitudes. [36] Each of these factors makes inroads into the class situation in its own way at times, but sometimes clustered together creating side-effects that kick the can of understanding of the situation further down the road. Almost every class is unique and hasty generalizations are out of place. But, for analysis and getting some understanding as to what appears to be happening, a study like this is essential since it provides models to look at or to avoid.

\section{Literature Review}

Showing up in class may have an influence on the performance of the students In the article by Credé, Roch and Kieszczynka (2010) [37] it is indicated that "class attendance without participation simply denotes physical presence". [38] Responding on this observation, some participants in this research pointed out that a student who just attend class but do not participate is like a statue in the class or just "filling-up the empty seats". Attendance by itself, while an important ingredient [39] to achieve in class any ac- 
ademic success, cannot guarantee that success. More than just sitting in class napping is needed.

Students either perform or retain. A number of studies investigated the cognitive and non-cognitive factors that affect these two aspects influencing both the attendance and grades. [40]

Although this research is currently investigating the effects of attendance on performance of ESL students in South Korea in a rural area, at Kyungpook National University at Sangju-Campus, and given the fact that some students are transported here from the city daily, a study was done on the effects of attendance on performance with business students in Nigeria, Africa. Ibrahim et al. studied three aspects at Ahmadu Bello University in Nigeria: 1 . The influence of attendance on performance; 2 . The influence of classroom participation on academic performance; 3. Difference in mean performance of students attending regularly and those who are not regular in attending; 4. Difference in mean performance of those students who participate in class and those who are not. 5. Difference in mean performance of those students who are doing both [to be a regular student and participating] as opposed to those who are only doing one [either only a non-regular student or participating/not]. They used a survey design method for 290 students for the academic years 2011/2012 and they used three secondary data: class attendance; records of participation and examination results. During the research they compared the scores of the students' achievements against the scores of attendance and participation. Similar with a number of earlier studies, e.g. Marburger (2001) that showed that students who missed class were significantly more likely to respond incorrectly to questions relating to material covered that day than students who were present; or Daniel (2006) who showed that "a significant link exists between absenteeism and learning" (Ibrahim 2014: 90); or Millis, Dyson and Cannon (2009) who indicated that "frequent attendees had higher passing rates on the examination and for the course than the passing rates for sporadic attendees" (Ibrahim 2014: 90); or the same scholars indicating that if a student participates well in the class then the scores in the examination will be also higher, it was also their finding.

Some investigators of these two aspects, attendance and grades, suggested that more is needed to fully understand the total picture. Chung (2004) indicated that a wider range of factors are needed to adequately understand what affects students' achievement. Although there are barriers for a student due to the fact that they are married and are parents, working 20 to 30 hours per week, volunteering, taking additional credit hours to graduate on time, struggling to overcome a learning or behavioral disability, Chung feels that they know they are going to miss class occasionally so they 
plan ahead. Several avenues are available to them for rescue: office hours, tutoring, e-mail correspondence, web sites, cell phones. This means that what goes on outside the classroom is for Chung just as important as what is going on in the classroom. Chung indicated that three studies dealt with at-risk populations for example: American Indian adults; developmental mathematics students; and developmental algebra students. Immerman (1982) worked with 23 American Indians and reported a significant difference between attendance and the final grade. Bereson, Carter and Norwood (1992) studied 263 Developmental Mathematics Freshman Students but they could not find any correlation between attendance and the final grade. Thomas and Higbee (2000) studied 119 Developmental Algebra students and focused on the aspect of involvement and achievement. [41]

It is because of these statements of Chung that one can say the factors of health, substance abuse, alcoholism, smoking even, game addiction, depression, self-perception, peer-awareness, and all that were listed supra, are necessary ingredients that could influence either the attendance record or if the attendance is perfect, the performance of the student.

Lifestyle studies were conducted by a number of scholars and the concept of wellness is prime for a study or this kind. There is no doubt that it affects either attendance or performance. It is not the intention of this particular research ongoing here to present the evidence for the role of lifestyle on attendance or its relation to the achievement of good grades on this campus in South Korea. Another study should be done for that utilizing a questionnaire elsewhere. The study by K.A. Cook, [42] is worth mentioning here. The study was done at Loyola University in order to see if the factors of alcohol, diet, tobacco and exercise play a role in the grade average attained.

"This study examined the relationship between a healthy lifestyle and college students' grade point average. A healthy lifestyle was measured by diet, exercise, sleep, alcohol use, and tobacco use. The participants included 52 undergraduate students from Loyola University New Orleans, who represented a range of ages, races, and gender." Whereas older studies do indicate that these factors influence the average grade, this study by Cook cancelled for their investigation alcohol, tobacco and exercise as factors influencing the average grade but these factors do lend to a perception that due to hangovers in overuse or lack of activity, that it may have contributed to a lower average grade. Cook admits that they had limitations. One of the handicaps in their research is that they do not know if the students were honest in their answers. They relied on their self-perception as measure and this may be noteworthy when considering that they are countering other findings on the role of alcohol on grade average or tobacco on the same or exercise. 
Many scholars have also investigated the role of the 'carrot and the stick' [43] and its role for attendance improvement or grade improvement. These are studies on educational policies regarding the effect that mandatory or voluntary attendance has on performance.

In the current study being undertaken here, our focus was mainly on the aspects of gender, attendance and grades. [44] Many studies were conducted in the past to evaluate the role that attendance plays on grades. [45] Then there were also the studies that investigated gender and its part in attendance or gender and its part as far as grades are concerned. Some focused on the role of the teacher impacting the attendance and grades. [46]Other studies charted the trends as far as grades are concerned for the years before 1994. [47]Attendance as focus was the study by M. VanBlerkon in 1992. [48]

\section{Methodology}

Before you begin to format your paper, first write and save the content as a separate text file. Keep your text and graphic files separate until after the text has been formatted and styled. Do not use hard tabs, and limit use of hard returns to only one return at the end of a paragraph. Do not add any kind of pagination anywhere in the paper. Do not number text heads-the template will do that for you. Finally, complete content and organizational editing before formatting. Please take note of the following items when proofreading spelling and grammar:

\subsection{Participants}

The number of participants in total over the period 2012-2016 was 3,963 students in Freshman English at a countryside campus (Sangju) for Kyungpook National University. In the year 2016, only the first semester were calculated in this research. For many of the years mentioned, the students were brought in by busses to the campus from urban centers or surrounding bigger towns. For the years 2012-2013 two teachers provided their data, namely Graham and Koot and for the period 2014-2016, three teachers provided data, namely Graham, Koot and Andy. Of the 3,963 students, 2,826 were males and 1,136 females.

\subsection{Data Collection}

The data was collected in the following way. There was no survey investigating the students' viewpoints but what was done is to take the final grade-sheets of the teachers and calculate the absences by males as opposed to the absences by females in each class and for each teacher for this period running between 2012 until 2016. The final grades were then computed and the average of each teacher was brought together. Then the av- 
erage of all three teachers for males and females were calculated and placed on a line graph to show the ebb and flow for the genders male and female over this period. The attempt was not to show the individual differences between the teachers regarding grades or absences, but to demarcate the trend of the performances of the students for each semesters of each year between 2012 to the $1^{\text {st }}$ Semester of 2016 .

\subsection{Data Analysis}

\begin{tabular}{|l|l|l|l|l|l|l|}
\hline \multicolumn{7}{|c|}{} \\
\cline { 2 - 8 } \\
\cline { 2 - 8 } & Graham & & Koot & & Andy & \\
\cline { 2 - 8 } & Male & Female & Male & Female & Male & Female \\
\hline $2012 / 1$ & 97.16 & 97.44 & 96.53 & 97.44 & 0.00 & 0.00 \\
\hline $2012 / 2$ & 95.21 & 96.52 & 98.90 & 99.14 & 0.00 & 0.00 \\
\hline $2013 / 1$ & 94.80 & 96.79 & 97.14 & 98.72 & 0.00 & 0.00 \\
\hline $2013 / 2$ & 95.68 & 96.89 & 98.55 & 98.46 & 0.00 & 0.00 \\
\hline $2014 / 1$ & 95.38 & 98.15 & 98.56 & 98.47 & 97.04 & 96.91 \\
\hline $2014 / 2$ & 94.88 & 95.48 & 97.19 & 96.24 & 96.58 & 97.92 \\
\hline $2015 / 1$ & 96.48 & 97.31 & 99.40 & 99.15 & 96.47 & 97.12 \\
\hline $2015 / 2$ & 96.29 & 97.01 & 99.77 & 99.63 & 96.40 & 97.76 \\
\hline Summary & \multicolumn{7}{|c|}{$96.92 \%$} & & & \\
\hline $\begin{array}{l}\text { Average male attendance } \\
\text { Average female attendance } 97.63 \%\end{array}$ & & & \\
\hline
\end{tabular}

Figure 1. Male and Female Attendance 2012 - 2015.

\begin{tabular}{|ll|l|l|l|l|l|}
\hline $\begin{array}{l}\text { Semester } \\
2012 / 1\end{array}$ & $\begin{array}{l}\text { Male } \\
\text { 96.85 }\end{array}$ & \multicolumn{1}{l}{$\begin{array}{l}\text { Female } \\
97.44\end{array}$} \\
$2012 / 2$ & 97.06 & 97.83 & $2012 / 1$ & 96.85 \\
$2013 / 1$ & 95.97 & 97.76 & $2013 / 2$ & 97.06 & Andy & \\
\cline { 2 - 8 } & 97.1 & 95.97 & Male & Female \\
\hline $2013 / 2$ & 97.12 & 97.68 & $2013 / 2$ & 97.12 & 0.00 & 0.00 \\
\hline $2014 / 1$ & 96.99 & 97.84 & $2014 / 1$ & 96.99 & 0.00 & 0.00 \\
\hline $2014 / 2$ & 96.22 & 96.55 & $2014 / 2$ & 96.22 & 0.00 & 0.00 \\
\hline $2015 / 1$ & 97.45 & 97.86 & $2015 / 1$ & 97.45 & 0.00 & 0.00 \\
\hline $2015 / 2$ & 97.49 & 98.13 & $2015 / 2$ & 97.49 & 97.04 & 96.91 \\
\hline Semester & Male & Female & Semester & Male & 96.58 & 97.92 \\
\hline $2012 / 1$ & 96.85 & 97.44 & $2012 / 1$ & 96.85 & 96.47 & 97.12 \\
\hline $2012 / 2$ & 97.06 & 97.83 & $2012 / 2$ & 97.06 & 96.40 & 97.76 \\
\hline $2013 / 1$ & 95.97 & 97.76 & $2013 / 1$ & 95.97 & & \\
\hline $2013 / 2$ & \multicolumn{7}{|c|}{97.12} & 97.68 & $2013 / 2$ \\
$2014 / 1$ & \multicolumn{7}{|c|}{96.99} & 97.84 & $2014 / 1$ \\
\hline
\end{tabular}

Figure 2. Average Attendance Percentage Among all Teachers. 


\begin{tabular}{|c|c|c|c|c|c|c|}
\hline Semester & Male\% & Female $\%$ & Semester & Male $\%$ & Female $\%$ & Semester \\
\hline $2012 / 1$ & 77.36 & 83.91 & $2012 / 1$ & 77.36 & 83.91 & $2012 / 1$ \\
\hline $2012 / 2$ & 81.68 & 87.41 & $2012 / 2$ & 81.68 & 87.41 & $2012 / 2$ \\
\hline $2013 / 1$ & 78.60 & 84.29 & $2013 / 1$ & 78.60 & 84.29 & $2013 / 1$ \\
\hline $2013 / 2$ & 82.60 & 87.61 & $2013 / 2$ & 82.60 & 87.61 & $2013 / 2$ \\
\hline $2014 / 1$ & 81.61 & 85.71 & $2014 / 1$ & 81.61 & 85.71 & $2014 / 1$ \\
\hline $2014 / 2$ & 82.89 & 86.06 & $2014 / 2$ & 82.89 & 86.06 & $2014 / 2$ \\
\hline $2015 / 1$ & 80.35 & 84.26 & $2015 / 1$ & 80.35 & 84.26 & $2015 / 1$ \\
\hline $2015 / 2$ & 82.17 & 87.55 & $2015 / 2$ & 82.17 & 87.55 & $2015 / 2$ \\
\hline $2016 / 1$ & 82.93 & 85.30 & 2016/1 & 82.93 & 85.30 & $2016 / 1$ \\
\hline Semester & Male\% & Female $\%$ & Semester & Male $\%$ & Female $\%$ & Semester \\
\hline
\end{tabular}

Figure 3. Student Average Scores among all teachers.

Figure Labels: Use 8 point Times New Roman for Figure labels. Use words rather than symbols or abbreviations when writing Figure axis labels to avoid confusing the reader. As an example, write the quantity "Magnetization", or "Magnetization, M", not just "M". If including units in the label, present them within parentheses. Do not label axes only with units. In the example, write "Magnetization $(\mathrm{A} / \mathrm{m})$ " or "Magnetization $\left(\mathrm{A} \cdot \mathrm{m}^{-1}\right)$ ", not just "A/m". Do not label axes with a ratio of quantities and units. For example, write "Temperature (K)", not "Temperature/K".

\section{Results and Discussions}

It is for each semester of a year between 2012-2016 but in 2016 only the first semester. The teacher's individual averages have been combined to get an overall average for each semester.

\subsection{Grading Policies and Standards of Marking}

It is evident from the results of the three teachers that their grades display individual differences or individual marking systems but that been said, they also displayed the same trend over the period regardless of the differences. What this indicates is that even though they acted independently, there is a constant "self-canonized standard" internalized in each teacher that without communication about it to each other during grading, they experience the same up and down trend overall for these years, yet at different results for the number of A's allocated. [49] That is very encouraging since it means 
that the teachers are not allocating grades with random "feelings" and ad hoc impressions in an erratic uncontrolled manner. [50] The University also encourages through the textbook that grading is multifaceted. It provides opportunity for students to get feedback on how they understand the information and how they need to improve. Students are to a greater degree by some teachers more than others, involved in scoring each other. [51] The culture of grading is understood and emphasized by all teachers among themselves at this campus. There are outcries across the globe that one should create a culture of learning not grading. [52].

\subsection{Increase in Compatibility Led to Increase in Grades-theory}

It is noticeable that in every year, the average for both males and females is higher in the second semester. Why is that? Perhaps students have a better understanding of the standards expected from them in terms of portfolio completion, writing competencies [53] and presentation skills. This will explain the rise in the second semester by both groups.

What also needs to be addressed is the outperforming of one gender over another for a particular semester. Females are better than males but the increase in a particular gender performance for some semesters shows increase from what is expected to be their average curve over the period of past performances. These are "pockets" of increase that needs explanations. If the expectations of the teacher is better understood a second time the question that should be posed is what hindrances were there in the first round from the instructor that could have prevented them from understanding fully what their teachers' expected from them? What barriers interfered with the ESL communication between the source language and the target language?

\subsection{Adaptation Strategies during Transition}

Wang et al found [54] that students who live in the countryside find adapting more difficult than those from urban areas. Adaption was determined not only by coping strategies but also social support. This aspect is very important for KNU Sangju Campus for the campus is remote from the main centers of temptation of downtown. Across the main-gate are some drinking places, convenient stores, restaurants and coffee shops, PC and Game Rooms as well as accommodation newly built, but other than that, nature is the friend of the student on this campus and this demographic factor facilitates purportedly friendship so that bonds are closer in a wider scale than it would have been in the 'concrete jungle' of the city. This 'wider circle of friends' opportunity at Sangju Campus, may be a contributive factor to positive outcomes such as "retention, quality of college life, ability to deal with 
academic stress, satisfaction with social and academic aspects of college life, and college adjustment". [55]

Successful students are normally seen as those who remain in college, enjoy psychological well-being and performing well academically. [56] For some students the transition may be stressful from highschool to University. It is suggested that 'the factors influencing first-year students' adaptation to college are complex and not have a clear conclusion in past studies". Wang et al investigated to see if the family or the individual cope strategies are playing strong parts in the success of transition adaptation. The Demographic variables in Wang et al's study that affects Adaptation Behavior in College were: only child; dialect speaking; city/countryside; family income and the major involved. [57] They found that social support led to coping strategies that in turn led to psychological health, which then ultimately affected the shape that the behavior adaptation is going to take in college. [58] The parents, college, society and friends are all necessary to give the students more support and help "in order to stimulate them to mediate their emotion positively, and spend the adaptation period as quickly as possible". [59]

Does it mean that females receive more social support that helps their coping strategies so that they are performing better than males during the transition period? Is the first semester the transition period from high school to university and after summer that adaptation is completed explaining the higher wave every year for both males and females in the second semester on the line graph above?

\subsection{South Korean GDP for the Same Period 2012-2016 and Attendance Grades}

A question that came up during the study by some researchers was whether there is a link between the socio-parental input or "table-talk" of the family alternating or affecting the motivation of the student, the attendance and performance statistics at the University of the countryside, the GDP of the country over a period of 2012-2016, and also the historical events in and around the country or so-called "national news". There is just enough data available to make a probe here into this question, but unfortunately such a study requires a doctoral or master level of research or another venue than this research to answer it more decisively.

- Economic Highlights in South Korea between 2012-2015

The statistics of economy of that period in South Korea was as follows. Volume and Value of Exports over the same period indicated that although there was large volume of exports in 2010 it dropped in 2011 and very much in 2012 to almost touch the $0 \%$ line and continued to creep along that line until present. The values of the exports have decreased in 
2015 to $-10 \%$ [60] The unemployment rate went down from $3.35 \%$ in 2012 to $3.15 \%$ in 2013 sliding down to almost 3\% in 2014, but increased from then on upwards to $3.65 \%$ at the end of 2015. [61] Bloomberg concluded that South Korea's economy expanded 2.6\% in 2015 from a year earlier, the slowest pace since 2012 . Industrial production was $1.5 \%$ in 2012; 0.7 in 2013; 0.3 in 2014; -0.6 in 2015. Annual exports in 2012 were $-1.3 \%$; in 2013 it was 2.1\%; in 2014 it was 2.3\%; and in 2015 it was $-8.0 \%$. Unfortunately, we do not have student interviews to evaluate whether their parental counsel at table-talks at home played any role in the increase of their motivation at school. If, for example, the father is struggling financially because the economy is down and would negatively speak about it at a table-talk, the student may come back to school with a survival "extra" push-drive to combat the negative outlook on the future by his/her own performance at school in academics. [62].

- Comparing the GDP of South Korea for 2012-2016 with the Final Grades of the Genders at KNU Sangju Campus

The GDP in South Korea was 2.3 in 2012. Profits were 754 in the 3rd quarter of 2012 but lost $-2,513$ in the 4th quarter. Profits in 2013 first quarter were 1,661 but dropped in second quarter to 335 and 3rd quarter to 51 and 4th quarter to a loss of $-1,365$. In 2014 1st quarter it was 1,$103 ; 2$ nd quarter dropped to 238 . The third quarter were -92 losses and the 4 th quarter 441 . The first quarter of 2015 was 559 and increased to 818 in the second quarter but crashed to $-6,024$ in the 3rd quarter and $-2,125$ in the 4th quarter. In 2016 1st quarter it was up 236 winning and 20 in the second quarter.

At KNU Sangju Campus the performance in grades during the 1st and 2nd quarter was $83.91 \%$ for females and $77.36 \%$ for males in 2012 . For the 3rd and 4th quarters in 2012 the female performance was measured at $87.41 \%$ and the males at $81.68 \%$. Did the worldwide economy meter play a role in the seriousness of the increased performance? This point is worth noting as one will see further on with the slump in the world economy in 2015 and the students output in that year. The GDP in South Korea was 2.3, very low in this year.

In the 1st and 2nd quarters of 2013 the female performance measured $84.29 \%$ average close to the first and second quarters of 2012 . The male performance average measured for the same period $78.60 \%$. In the 3rd and 4th quarters of 2013 the female performance was $87.61 \%$ and the male performance $82.60 \%$. The GDP in South Korea during this period was 2.9. The GDP increase in South Korea also displayed an increase of female and male performances.

The 1st and 2nd quarters of 2014 saw female students performing an av- 
erage $85.71 \%$ and males $81.61 \%$. For males this was quite high. The GDP in South Korea was 3.9 during this semester. It was the highest for these years that is under consideration.

For the 3rd and 4th quarters of 2014 both females with $86.06 \%$ and males with $82.89 \%$ maintained the momentum of the first quarter. The GDP in South Korea fell to 3.5 and 3.4. The males were high this year.

The next year, namely the 1st and 2nd quarters of 2015 the females gained $84.26 \%$ and the males $80.35 \%$ still higher than the first semesters of 2013 or 2012 when they were in the seventies. Of course the achievement is relatively similar than in 2014 quarters 1st and 2nd or the first semester. The GDP of South Korea fell to 2.7 and 2.4 in this semester. The grades of the males during this shocking drop were higher than in 2012. The females were the same as in 2012 when the GDP was almost the same.

In the 3rd and 4th quarters of 2015 the female performance measured $87.55 \%$ which is close to what they achieved in the second semesters of 2012; 2013; almost in 2014 and now in 2015. The males remained also stable for the second semester with $82.17 \%$ which is similar to the second semester of 2014. The GDP of South Korea fell further to a shocking low of 2.2 but started a steep climb to 2.8 before the year was out. They were supposed to mirror either an increase (survivor motivation) or decrease (depression) in this event. This particular dip of the GDP in South Korea did not alter the performance of the female or the male students in South Korea at Sangju Campus. They did not slump back in their grades due to a gloomy outlook in South Korea and worldwide. It was a bad year in South Korea for the GDP but the females increased by $3 \%$ and the males by $2 \%$.

Considering the following year, the 1st and 2nd quarters of 2016 the females were the same as the 1st and 2nd quarters of 2014, but the males performed their best ever with $82.93 \%$. The GDP of South Korea climbed in the first semester to 3.1 but trended down to 2.8. Did the shock of the end of 2015 readjust our high school students to be more motivated in the first semester of 2016, especially the males?

Did the uncertainty in economy on the global markets and the GDP of South Korea of the second half of 2015, mirrored in at table-talks at home from the parents possibly made them resilient to overcome the negative with positive output? Especially the males since the females did not show that same increase as the males did in the first semester of 2016?

These are questions that we did not intend to answer decisively in this research and at present this part of our research calls for further investigation in the future with interviews, surveys, and other data applied to 
make it verifiable with controls. It is thus an open question that needs further research in the future.

\begin{tabular}{|llll|} 
& GDP South Korea & \multicolumn{2}{l|}{ Attendance Scores } \\
& & male & female \\
2012A & 3.5 & 3.868 & 4.1955 \\
2012B & 2.3 & 4.084 & 4.3705 \\
2013A & 2.7 & 3.93 & 4.2145 \\
2013B & 2.9 & 4.13 & 4.3805 \\
2014A & 3.2 & 4.0805 & 4.2855 \\
2014B & 3.9 & 4.1445 & 4.303 \\
2015A & 2.7 & 4.0175 & 4.213 \\
2015B & 2.9 & 4.1085 & 4.3775 \\
2016A & 3.1 & 4.1465 & 4.2855 \\
& & & \\
\hline
\end{tabular}

Figure 4. Comparing the proliferations of GDP with the Attendance Scores.

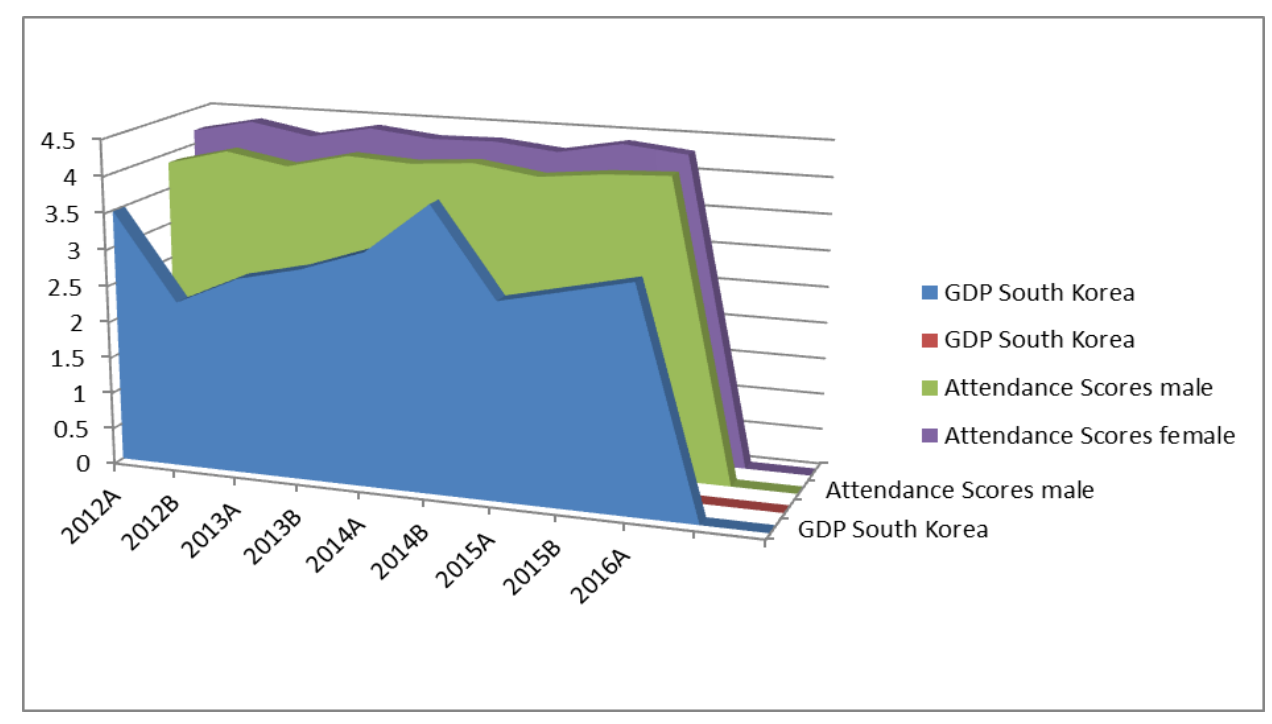

Figure 5. Effect of an Export-driven Economy of Korea on Students performance [64].

- Attendance in Genders during the Slump of the Second Quarter of 2015.

The attendance of the students for males and females displayed for the year 2015 for all three teachers a highest attendance constancy (rounded off) Graham 96\% males 97\% females; Koot 99\% males, 99\% females; and Andy $96 \%$ males, $97 \%$ females, higher for every teacher than the previous years. 
Of course females are attending better than males overall. World and South Korean financial stress did not decrease the attendance conscientiousness seemingly for our students at KNU Sangju Campus.

- Environmental Beauty and Nature's Impact on Students' Performance Whether the urban campus will be different than the countryside campus was not investigated here. These statistics will help to establish the role of environment: fresh air, beauty of nature, absence of hindrances to study, more time for reflection, 'cognitive escapism' played on the good performance of the students amid financial woes of the world at large. What this factor means is that the 'concrete jungle' of the urban setting may have a negative influence over students' natural cognitive development and factors like pollution may add to the stress for urban students, but that KNU Sangju Campus students are fortunate to enjoy fresh air, beautiful nature, tranquility, peace and slow pace that are excellent ingredients for an holistic educational development of the student. Transportation to and from the school may add to stress in an urban setting that is not present at the countryside campus of KNU. Such a study should still be conducted to ascertain the effect of nature environment on the velocity of performance of students' attendance rate and grades for males and females at the two campuses.

- Lifestyle as Influence on Students' Performance

The demographics of KNU Sangju Campus at present provide an ideal educational environment where nature plays a larger role than in urban centers. It may also affect the lifestyle of the students on this campus and wellness, [65] as defined in the literature, and the concept of holistic health regarding control over aspects of nutrition, exercise, fresh air, alcohol intake or abstention of it, smoking habits, sleeping habits, regular water intake, all that may affect the motivational level of the students during performance and contribute to their attendance records and grades. These aspects were unfortunately not scientifically tested by this research with a survey and suggestions here are mere observational side comments. It would be interesting to compare the two campuses regarding these lifestyle aspects to see how it affects their attendance and grades. It will also help solve the question regarding the role of the environment in the statistics of the attendance and grades of males and females.

\section{Conclusion}

Females are still outperforming males at KNU Sangju Campus for the years 2012-2016 first semesters. The line graph of the totals of the averages of the three teachers indicates that both genders in some years increased together and in some years decreased together. There were years when the males increased in performance but the females remained dormant or regular in 
theirs. For the 3rd and 4th quarters in 2012 both genders increased and it happened that this period saw an economic slump in the world. In the 3rd and 4th quarters of 2013 the economic fall in the world reflects an increase in performance of both genders at KNU Sangju Campus.

The year 2014 saw the genders performing stable throughout the year. This stability in gender performance is maintained with no decrease and increase until the end of the 1st semester of 2015. In the 2nd semester of 2015 the gender performance increased similarly to the second semesters of 2012 and 2013 although the World Economy saw a retreat during this time. A slight normalization came in the 1st semester of 2016 with South Korea's GDP and the genders on KNU Sangju Campus performed similarly to the 1st semester of 2014. The overall result is that doom and gloom in the financial markets affects the male performance at KNU Sangju Campus positively so that there is an increase. Grades are higher under difficult financial times for both genders, but in the first semester of 2016, especially for the males.

\section{References}

[1] Ackerman, M. E., \& Morrow, J. E. (2007) A principal components analysis and validation of the Coping with the College Environment Scale. Journal of College Student Retention: Research, Theory \& Practice, 9(2), 133-148.

[2] Adebayo, B. (2008). Cognitive and non-cognitive factors affecting the academic performance and retention of conditionally admitted freshman. Journal of College Admission, 200, 15- 21.

[3] Ahmed, A.A., Zeynab, A.Y., Ahmed, M.D. (2013) The Effect of Student's Attendance on Academic Performance: A Case Study at Simad University Mogadishu. Academic Research International Vol. 4(6), November 2013: 409-417.

[4] Ajiboye, J. O., Tella, A. (September 2006) Class Attendance and Gender Effects on Undergraduate Students' Achievement in a Social Studies Course in Botswana. Research Gate Online. University of Botswana. Retrieved on $11^{\text {th }}$ ofJuly2016at:

https://www.researchgate.net/publication/242178277

[5] Alawiyah, T., U. Sulistiyo, (2018, July) The Influence of Students['] Motivation toward Students' Achievement in English Subject at SMP N 12 Muaro Jambi. International Journal of Language Teaching and Educa$\begin{array}{lllll}\text { tion, } & \text { Volume } & 2, & \text { no. } & \text { 145-156. }\end{array}$ https://online-journal.unja.ac.id/index.php/IJoLTE/article/view/5000/ $\underline{3639}$

[6] Al-Emadi, A., (2003) Gender. Stream, achievement goals, locus of control, strategies and academic achievement of Emerati College Students . Journal of Humanities and Social Sciences 19. (1).

[7] Allen, J., Robbins, S., Casillas, A., \& Oh, I. (2008) Third-year college re- 
tention and transfer: Effects of academic performance, motivation, and social connectedness. Research in Higher Education, 49(7), 647-664.

[8] American Heart Association: The benefits of daily physical activity (2004). Retrieved March 28, 2004, from

http://www.americanheart.org/presenterjhtml?idetifier $=764$

[9] American Lung Association Fact Sheet: Smoking. (2003) Retrieved March 4, 2004, from http://www.lungus.org/tobacco/smoking factsheet99.html

[10] Anding, J. D., Suminski, R.R., \& Boss, L. (2001) Dietary intake, body mass index, exercise, and alcohol: Are college women following the dietary guidelines for Americans. Journal of American College Health, 49, 167-171.

[11] Anikeeff, M. (1954) The Relationship Between Class Absences and College Grades. Journal of Educational Psychology, 45, 244-249.

[12] Archer, J., Probert, B. S., \& Gage, L. (1987) College students' attitudes toward wellness. Journal of College Student Personnel, 2, 311-317.

[13] Astin, A. (1993) What Matters in College. Liberal Education, 79(4), 4-15.

[14] Bank, B. J., Biddle, B. J., \& Slavings, R. L. (1994) First semester grades, thought modes, and undergraduate persistence. Contemporary Educational Psychology, 19, 416-429.

[15] Ballentine, H. M., (April 20, 2010) The Relationship Between Wellness and Academic Success in First-year College Students. Dissertation submitted to the faculty of the Virginia Polytechnic Institute and State University. Phd in Educational Leadership and Policy Studies. Blacksburg, Virginia.

[16] Baltimore, M. D. (1999) Maryland State Department of Education. Maryland school performance report: Executive summary.

[17] Beaulieu, R.P (1985) Positive and punitive contingencies and the control of absenteeism. College Student Journal 18, 126- 130.

[18] Beddoe, A. E., \& Murphy, S. O. (2004) Does mindfulness decrease stress and foster empathy among nursing students? Journal of Nursing Education, 43(7), 305-312.

[19] Berenson, S.B; Carter, G.; \& Norwood, K.S.(1992)The at-risk student in college developmental algebra. School Science and Mathematics, 92 (2), 55-58.

[20] Biegel, S., (2000)The interfaces between attendance, academic achievement, and equal educational opportunity. The report of consent decree monitoring team .U.S District Court, Northern District of California.

[21] Boloz, S. A. (1983). Combating student absenteeism: strategies for raising attendance and achievement. Journal of American Indian Education, $22,25-30$.

[22] Bratti, M., \& Staffolani, S. (2002) Student Time Allocation and Educational Production functions, Working Paper Number 170, Economics 
Department, University of Ancona.

[23] Brocato, J. (1989) How Much Does Coming to Class Matter? Some evidence of class attendance and grade performance. Educational Research Quarterly, 3, 2-6.

[24] Brookhart, S. M. (November 2011) Starting the Conversation About Grading. Educational Leadership, 69(2), 10-14.

[25] Brunsma, D. \& Rockquemore, K. (1998) Effects of student uniforms on attendance, behavior problems, substance use and academic achievement. The Journal of Educational Research, 92, 53-62.

[26] Buboltz, W.C., Brown, F., \& Soper, B. (2001) Sleep habits and patterns of college students: A preliminary study. Journal of American College Health, 50, 131-135.

[27] Bucklew, W., Daly, D., \& Coffield, K. (1986) , Relationship of Initial Class Attendance and Seating location to Academic Performance in Psychology Classes. Bulletin of the Psychonomic Society, 24, 63-64.

[28] Budd, G.M., \& Preston, D.B. (2001) College students attitudes and beliefs about the consequences of smoking:

[29] Development and normative scores of a new scale. Journal of the American Academy of Nurse Practitioners, 13, 421-427.

[30] Burtless, G. (1995) The Case for Randomized Field Trials in Economic and Policy Research. Journal of Economic Perspective, 9, 63-84.

[31] Cabrera, A. F., Nora, A., Terenzini, P. T., Pascarella, E., \& Hagedorn, L. S. (1999) Campus racial climate and the adjustment of students to college. The Journal of Higher Education, 70(2), 134-160.

[32] Camera, W. J., \& Echternacht, G. (2000) The SAT[R] I and high school grades: Utility in predicting success in college.

[33] Research notes. (College Entrance Examination Board Rep. No. CB-RN-10). New York, NY: The College Board.

[34] Cavigla-Harris., J.L. (2004 Attendance rates and academic achievement: Do attendance and policy and class size effects impact student performance? Retrieved from http://www.ssm.com/abstract $=605462$. on $27 / 11 / 2005$

[35] Chen, J. \& T., L. (2008) Class attendance and exam performance: A randomized Experiment. Journal of Economic Education, 213-227.

[36] Chung, C.J. (2004) Impact of attendance, instructor contact, and homework completion on achievement in a developmental logic course. Research and Teaching in Developmental Education, Vol. 20(2). Retrieved on the $31^{\text {st }}$ of August 2016 from

https://www.questia.com/library/journal/1P3-589967561/the-impact -of-attendance-instructor-contact-and

[37] Clair, K. L. (1999) A case against compulsory policies in higher education. Innovative Higher Education, 23, 93), 171-180.

[38] Clay, T. and Breslow, L. (2006) Why students don't attend class. MIT 
Faculty Newsletter, 18 (March/April), 6-7.

[39] Clifton, R. A., Perry, R. P., Roberts, L. W., \& Peter, T. (2008) Gender, psychological dispositions, and the academic achievement of college students. Research in Higher Education, 49(8), 684-703.

[40] Clump, M.A., Bauer, H. and Whiteleather, A. (2013) To attend or not attend: is that a good question? Journal of Instructional Psychology 30: 220-224.

[41] Connolly, K. (2000) The relationship among wellness, mattering, and job satisfaction. Unpublished doctoral dissertation, University of North Carolina at Greensboro, Greensboro, NC.

[42] Costa, A. R. (2004) The Relationship Between Health and College Students` Grade Point Average. National Undergraduate Research Clearinghouse, $7 . \quad$ Available online http://www.webclearinghouse.net/volume/. Retrieved August 31, 2016.

[43] Covington. M., \& Omelich, C. L. (1987) "I knew I could before the exam": A test of the anxiety-blockage hypothesis. Journal of Educational Psychology 79, 393-400

[44] Credé, M. Roch, S., and Kieszczynka, U. (2010) Class attendance in college: A meta-analytic review of the relationship of class attendance with grades and student characteristics. Review of Educational Research 80, 272-295.

[45] Creswell, J. W. (2005) Educational research: Planning, conducting, and evaluating quantitative and qualitative research (2nd ed.). Upper Saddle River, NJ: Pearson.

[46] Crose, R., Nicholas, D. R., Gobble, D. C., \& Frank, B. (1992) Gender and wellness: A multidimensional systems model for counseling. Journal of Counseling \& Development, 71, 149-156.

[47] Daniel, R. M. (2006) Does Mandatory Attendance Improve Student Performance?

Journal of Economic Education, 148-155. Retrieved from https://kathleenmihokwilmu.wikispaces.com/

[48] DeBerard, M. S., \& Julka, D. L. (2000) Correlation of gender with 1st semester GPA and 1st semester academic warning in college freshmen. Unpublished raw data.

[49] DeBerard, M. S., Speilmans, G. I., \& Julka, D. L. (2004) Predictors of academic achievement and retention among college freshmen: A longitudinal study. College Student Journal. 38(1), 66-81.

[50] Department of Health and Human Services \& U.S. Department of Agriculture. (2000) Nutrition and Your Health: Dietary Guidelines for American. Retrieved March 4, 2004, from http://www.health.gov/dietaryguidelines/dga2000/document/buil.ht $\underline{\mathrm{m}}$

[51] Dekalb, J. (1999) Student truancy. (Report No. EDO-EA-99-1). Wash- 
ington, DC: Office of educational research and improvement. (ERIC Document Reproduction Service No. ED429334).

[52] Devadoss, S. \& Foltz, J. (1996) Evaluation of Factors Influencing Student Class Attendance and Performance. American Journal of Agriculture Economics, 78, 499-507.

[53] Diego, M.A., Field, T.M., \& Sanders, C.E. (2003) Academic performance, popularity, and depression predict adolescent substance abuse. Adolescence, 38, 35-42.

[54] Dolton, P., Marcenaro, D. \& Navarro, L. (2003) The Effective Use of Student Time: a Stochastic Frontier Production Function Case Study. Economics of Education Review, 22, 547-560.

[55] Dueden, C., \& Ellis, V. (1995) The effect of attendance on student Learning in Principles of Economics. American Economics Review, 343-346.

[56] Dynneson, T.L \& Gross, R.E. (1999) Designing effective introduction for secondary school social studies .Upper Saddle River: Prentice-Hall.

[57] Ebi, M. (2012) For First-Year Students: How does class Participation relate to other Academic Behaviors and Outcomes? Retrieved from http://www.webebi.com/community/research/

[58] Education Policy Institute. (2004) The art of student retention. Virginia Beach, VA: Author, Edwards K. J.,

[59] Hershberger, P. J, Russell, R. K., \& Markert, R. J. (2001). Stress, negative social exchange, and health symptoms in university students. Journal of American College Health, 50(2), 75-79.

[60] Eno, D., McLaughlin, G. W., Brozovsky, P., \& Sheldon, P. (1998, May) Predicting freshman success based on high school record and other measures. Paper presented at the Annual Forum of the Association for Institutional Research, Minneapolis, MN.

[61] Enochs, W. K. (2001) Wellness and adjustment in college freshman based on type of residence hall and gender. Unpublished doctoral dissertation, University of Arkansas.

[62] Evans, N. J., \& Broido, E. M. (1999) Coming out in college residence halls: Negotiation, meaning making, challenges, supports. Journal of College Student Development, 40(6), 658-668.

[63] Engs, R. C. (1992) Student Health and Lifestyle Questionnaire. Indiana University. Retrieved February 4, 2004, from http://www.indiana.edu/ engs/quest/shq.html

[64] Engs, R.C. (2000) Alcohol and Drug Questionnaire. Indiana University. Retrieved February 4, 2004, from http://www.indiana.edu/ engs/quest/uk.html

[65] Feenstra, S. J., Banyard, L. V., Rines, E. N., \& Hopkins, R. K. (2001) First-year students' adaptation to college: The role of family variables and individual coping. Journal of College Student Development, 42(2), 106-113. 
[66] Field, T., Diego, M., Sanders, C.E. (2001) Exercise is positively related to adolescents`relationships and academics. Adolescence, 36, 105-110.

[67] Friedman, P., F. Rodriguez, and J. McComb. (2001) Why students do and do not attend classes. College Teaching 49: 4124-133.

[68] Gaudine, A. P. and Saks, A. M. (2001) Effects of an absenteeism feedback intervention on employee absence behavior. Journal of Organizational Behavior 22: 15-29.

[69] Garner, H. L. (2006) Humor in pedagogy: How ha-ha can lead to aha! College Teaching, 54(1), 177-180.

[70] George, D., Dixon, S., Stansal, E., Gelb, S., Pheri, T. (2008) Time diary and questionnaire assessment of factors associated with academic and personal success among university undergraduates. Journal of American College Health 56(6), 706-715.

[71] Granello, P. F., (1999) College students' wellness as a function of social support and empathetic ability. Journal of College Counseling. 2, 110-120. 85

[72] Graunke, S., \& Woosley, S. (2005) An exploration of the factors that affect the academic success of college sophomores. College Student Journal, 39(2), 367-377.

[73] Green, R. P. (1993) A correlation between attendance and grades in a first year psychology class. Canadian Psychology, 34,(2), 201-202.

[74] Gunn, P. (1993) A Correlation between Attendance and Grades in a First-year Psychology Course. Canadian Psychology, 34, 201-202.

[75] Haberman, S., \& Luffey, D. (1998) Weighing in college students diets and exercise behaviors. Journal of American College Health, 46, 189-191.

[76] Han, J., L., Dinger, M., K., \& Hull, H., R. (2008) Changes in women's physical activity during the transition to college. American Journal of Health Education, 39(4), 194-199.

[77] Hancock. (1996) Gender and developmental differences in the academic study behaviours of elementary school children. Journal of Experimental Education 65, 18-39.

[78] Hansen, T. L, jr. (1990) A positive reinforcement program for controlling student absenteeism. College Student Journal 24, 307- 312.

[79] Halpern, D.F. (1996) A process-oriented model of cognitive sex differences . Learning and Individual differences, 8, 3-24.

[80] Harackiewicz, J. M., Barron, K. E., \& Tauer, J. M. (2002) Predicting success in college: A longitudinal study of achievement goals and ability measures as predictors of interest and performance from freshman year through graduation. Journal of Educational Psychology, 94(3), 562-575.

[81] Harris, W. Diet and Lifestyle Questionnaire. (n.d.). Retrieved February 4, 2004, from

http://www.vegsource.com/harris/diet.htm

[82] Health Sciences and Athletes. (2004) Nutrition Assessment. El Camino 
College. Retrieved February 4, 2004, from

http://www.youth.net/ecc/nutrition.html

[83] Hedges, L.V. (1992) Meta-analysis. Journal of Educational Statistics, $17,279-296$

[84] Hedges, L.V. \& Nowell, A. (1995) Differences in mental tests scores, variability, and numbers of high scoring individuals. Science, 269, 41-45.

[85] Hettler, B. (1980) Wellness promotion on a university campus: Family and community health. Journal of Health Promotion and Maintenance, 3, 77-95.

[86] Hicks, R. A., Guista M., Schretlen, D., \& Pellegrini, R. J. (1980) Habitual duration of sleep and divergent thinking. Psychological Reports, 46, 426.

[87] Horn, L., \& Peter, K. (2003) What colleges contribute: Institutional aid to full-time undergraduates attending 4-year colleges and universities (Report No. NCES-2003-157). Washington, DC: National Center for Education Statistics. (ERIC Document Reproduction Service No. ED476229).

[88] Hurtado, S., Carter, D. F., \& Spuler, A. (1996) Latino student transition to college: Assessing difficulties and factors in successful college adjustment. Research of Higher Education, 37(2), 135-158.

[89] Hoyles, D. (1998) Constructions of pupil absence in the British education service. Child and Family Social Work, 3 , 99-111.

[90] Huang, T. K., Harris, K.J., Lee, R.E., Nazir, N., Born, W., \& Kaur, H. (2003) Assessing overweight, obesity, diet, and physical activity in college students. Journal of American College Health, 52, 83-86.

[91] Ibrahim, A., Abdullahi, U.M. (2014) Impact Appraisal of Classroom Management (Attendance and Participation) on Performance of Business Education Students in Ahmadu Bello University Zaria, Nigeria. Journal of Education and Practice Vol. 5(25), 86-92. Retrieved on the $31^{\text {st }}$ ofAugust2016 at

https://issuu.com/alexanderdecker/docs/impact appraisal ofclassroo m manag

[92] Institutional Benchmark Report. (2002) National survey of student engagement. Illinois State University.

[93] Irwin, J. D. (2007). The prevalence of physical activity maintenance in a sample of university students: A longitudinal study. Journal of American College Health, 56(1), 37- 41.

[94] Ishitani, T. T. (2003) A Longitudinal approach to assessing attrition behavior among first- generation students: Time-varying effects of pre-college characteristics. Research in Higher Education. 44(4). 443-449.

[95] Johnson, I. Y. (2006) Analysis of stopout behavior at a public research university: The multi- spell discrete-time approach. Research in Higher Education. 47(8), 905-934.

[96] Joseph, M., Yakhou, M. \& Stone, G. (2009) An educational institution's 
quest for service quality: customer's perspective. Quality Assurance in Education, 13 (1), 66-82.

[97] Kelci, L. L. (2013) Why go to class? Retrieved from http://collegelife.about.com/od/academiclife/qt/

[98] Keller, D., Crouse, J., \& Trusheim, D. (1993) Relationships among gender differences in freshman course grades and course characteristics. Journal of Educational Psychology, 85(4), 702-709.

[99] Kelly, M. (2015) Creating a Culture of Learning, not Grading. Retrieved on the 20th of September 2016 from

https://principalmkelly.com/2015/10/23/creating-a-culture-of-learni ng-not-grading/

[100] Kelly, W.E., Kelly, K.E., \& Clanton, R.C. (2001) The relationship between sleep length and grade-point average among college students. College Student Journal, 35, 84-86.

[101] Kevin, A.S. (2014) How important is Classroom Attendance for University Students? Retrieved from http://www.opednews.com/articles/

[102] Kirby, A. \& McElroy, B. (2003) The Effect of Attendance on Grade for First Year Economics Students in University college Cork". The Economic and Social Review, 34 (3), 311-326.

[103] Kirk, A. J. (2000) The Peer Effect on Academic Achievement among Public Elementary School Students. Research Education. Center for Data Analysis Report No 00-06.

[104] Korobkin, D. (1989) Humor in the classroom: Considerations and strategies. College Teaching, 36(4), 154-158.

[105] Kumar, A., \& Vaidya, A. K. (1982) Neuroticism in short and long sleepers. Perceptual and Motor Skills, 54 962. Kumar, A., \& Vaidya, A. K. (1984) Anxiety as a personality dimension of short and long sleepers. Journal of Clinical Psychology, 40 197-198.

[106] Launius, M. H. (1997) College student attendance: Attitudes and academic performance. College Student Journal 31:86-92

[107] Lee, G-L; Hwang, E-J; Janda, L. H.; Hong, S. (December 2015) Korean Home Learning Environment and Parent Characteristics Influencing Children's Expressive and Receptive Language Abilities. International Journal of Language and Linguistics 2(6), pages 1-12.

[108] Leppel, K. (2001) The impact of major on college persistence among freshman. Higher Education, 41, 327-342.

[109] Lewallen, W. (1993) The impact of being "undecided" on college-student persistence. Journal of College Student Development, 34,103-112.

[110] Lisa, L. (2014) School Attendance Push to Impel Importance of Going to Class Prized by Students and Educators.

Retrieved from http://www.huffintonpost.com/ 
[111] Mack, M. G., \& Shaddox, L. A. (2004) Changes in short-term attitudes toward physical activity and exercise of university personal wellness students. College Student Journal, (38)4, 587-584.

[112] Makinson, L. (2001) The relationship of moral identity, social interest, gender, and wellness among adolescents. Unpublished doctoral dissertation, University of North Carolina at Greensboro, Greensboro, NC.

[113] Mansaray, A. (1991) Social Studies methods 1. Ibadan Centre for External Studies Series, University of Ibadan, Ibadan,

[114] Nigeria. Myra, A, \& Sadker, D. (1994). Failing at fairness: How America's Schools cheat Girls New York: Simon \& Schuster.

[115] Mansfield, P. M., Pinto, M. B., Parente, D. H., \& Wortman, T. I. (2004) College students and academic performance: A case of taking control. NASPA Journal, 41(3), 551-567.

[116] McClanahan, R. (2004) What works in student retention? Iowa City, Iowa: ACT. 88 Mitchell, M. (2001). The relationship among acculturation, wellness, and academic self-concept in Caribbean American adolescents. Unpublished doctoral dissertation, University of North Carolina at Greensboro, Greensboro, NC.

[117] Marburger, D. R. (2001) Absenteeism and Undergraduate Exam Performance. Journal of Economic Education, Spring, 32(2), 99-110.

[118] McPartland, J., Balfanz, R., Jordan, W. \& Legters, N. (1998) Improving climate and achievement in a troubled urban high school through the talent development model. Journal of Education for Students Placed at Risk, 3, 337-361.

[119] Merry, S. and Darren, R. (2001) Encouraging Student Attendance. Association of Psychological Science, 14(9).

Retrieved from http://www.psychologicalscience.org/journals/

[120] Millis, R. M., Dyson, S. and Cannon, D. (2009) Association of classroom participation and examination performance in a first-year medical school course. Advances in Physiology Education 33(1), 139-143. Retrieved from http://www.ncbi.nlm.nih.gov/pubmed/19745038

[121] Moore, R. (2003) Helping Student succeed in Introductory Biology Classes: Does Improving Student's Attendance Also Improve Their Grades? Bioscience, 29(3), 17-25.

[122] Moore, R., Jensen, M., Hatch, J., Duranczyk, I., Staats, S., and Koch, L. (2003) Showing Up: The Importance of Class Attendance for Academic Success in Introductory Science Courses. The American Biology Teacher 65(5): 325-329.

Online accessed 9th of December 2016 at doi:http://dx.doi.org/10.1662/0002-7685(2003)065[0325:SUTIOC ]2.0.CO;2

[123] Myers, J. E. (1998) Manual for the Wellness Evaluation of Lifestyle. Palo Alto, CA: Mindgarden.

[124] Myers, J. E., \& Sweeney, T. J. (2004) The Five-Factor Wellness In- 
ventory (3rd ed.). Greensboro, NC.

[125] Myers, J. E., \& Sweeney, T. J. (Eds.). (2005) Counseling for Wellness: Theory, Research, and Practice. Alexandria, VA: American Counseling Association.

[126] NAEP (1994) Trends in Academic Progress (Washington, D. C; U.S. Government Printing Office.

[127] Nowell, A. (1998) Trend in gender difference in academic achievement from 1960-1994: An analysis of differences in mean, variance, and extreme sources. Sex Roles: A Journal of Research. Retrieved from http://www.findarticles.com/p/articles/mi 2294/is n/-v39/ai

[128] Public Schools of North Carolina. (2001).Strategies to improve instructional practices. Retrieved 22/11/2005 from

http://www.ncpublicschools.org/schoolimprovement/closingthegap/st rategies/movement

[129] Odell, C. W. (1923) The effect of attendance upon school achievement. Journal of Educational Research, 12, 422-432.

[130] One Person Health. Lifestyle and Nutrition Questionnaire. (n.d.). Retrieved February 3, 2004, from http://www.onepersonhealth.com/ISPs/Questionnaire.jsp

[131] Oso, W. Y. \& Onen, D. (2008) A General Guide to Writing Research Proposal and Report (2 ${ }^{\text {nded. }}$.).Kampala.

[132] Pagel, M. D., Erdly, W. W., Becker, J. (1987). Social networks: We get by with (and in spite of) a little help from our friends. Journal of Personality and Social Psychology, 53(4), 793- 804.

[133] Park, K. H. \& Kerr, P. M. (1990) Determinants of Academic Performance: a Multinomial Logit Approach". Journal of Economic Education, 21(2), 101-111.

[134] Pascarella, E. T., \& Terenzini, P. T. (1991) How College Affects Students, San Francisco: Jossey-Bass. Postsecondary Education Opportunity. (2009, March) College completion rates 1947 to 2007. (No. 201). Oskaloosa, IA: Author. 89

[135] Pate, R.R., Heath, G.W., Dowda, M., \& Trost S.G. (1996) Associations between physical activity and other health behaviors in a representative sample of US adolescence. American Journal of Public Health, 86, 1577-1582.

[136] Pilcher, J.J., \& Walters, A. S. (1997) How sleep deprivation affects psychological variables related to college students cognitive performance. Journal of American College Health, 46, 121-126.

[137] Plant, E. A., Ericsson, K. A., Hill, L. \& Asberg, K. (2005) Why study time does not predict grade point average across college students: Implications of Deliberate Practice for Academic performance. Contemporary Educational Psychology, 96-116.

[138] Pritchard, M. E., Wilson, G. S., \& Yamnitz, B. (2007) What predicts 
adjustment among college students? A longitudinal panel study. Journal of American College Health, 56(1), 15-21.

[139] Quinlan, T., Nelson, E. (24th November2015) "KoreanEconomicOutlookfor2016"Wells Fargo Securities. Online accessed on September 2016 at

https://www08.wellsfargomedia.com/assets/pdf/commercial/insights /economics/international-reports/korea-2016-outlook-20151124.pdf

[140] Reese, V. L., \& Dunn, R. (2008) Learning-style preferences of a diverse freshmen population in a large, private, metropolitan university by gender and GPA. Journal of College Student Retention: Research, Theory, \&Practice, 9(1). 95- 112.

[141] Reifman, A., \& Dunkel-Schetter, C. (1990) Stress, structural social support, and well-being in university students. Journal of American College Health, 38(6), 271-277.

[142] Richards, R. L., \& Casey, M. B. (1975, March) Creativity and academic motivation variables as predictors of achievement in a two-year college for educationally marginal students. Paper presented at the annual meeting of the American Educational Research Association, Washington, D.C.

[143] Roby, D. E. (2004) Research on school attendance and student achievement: A study of Ohio schools. Education Research Quarterly, 28(1), 3-14.

[144] Rocca, A. K. (2003) Student Attendance: A Comprehensive Literature Review. Journal on Excellence in College Teaching, 14, 85-107.

[145] Rodgers, J. R. (2001) A panel-data study of the effect of student attendance on academic Performance, Unpublished manuscript.

[146] Romer, D. (1993) "Do students go to class? Should they?" Journal of Economic Perspectives, 167-174.

[147] Rowe, K.J. (1988) Single-sex and mixed-sex classes: The effects of class type on student achievement, confidence and participation in mathematics. Australian Journal of Education, 32, 180-202.

[148] Sadler, W. E., Cohen, F. L., \& Kockesen, L. (1997, May) Factors affecting retention behavior: A model to predict at-risk students. Paper presented at the annual forum of the Association for Institution Research, Orlando, FL.

[149] Sax, L. J. (1997) Health trends among college freshman. Journal of American College Health, 45, 252-262.

[150] Sander, P., Stevenson, K., King, M. \& Coates, D. (2000) University student's expectations of teaching. Studies in Higher Education, 25(3), 309-329.

[151] Schmidt, R. (1983) "Who maximises what? A study in student time allocation". American Economic Review Papers and Proceedings, 23-28.

[152] Seo, D. C., Nehl, E., Agley, J., \& Ma, S. M. (2007) Relations between physical activity and behavioral and perceptual correlates among mid- 
western college students. Journal of American College Health, 56(2), 187-197.

[153] Shurts, M. (2004) The relationship among relationship efficacy, marital messages received, marital attitudes, and wellness in traditional age unmarried college students. Unpublished doctoral dissertation, University of North Carolina at Greensboro, Greensboro, NC.

[154] Shurts, M., \& Myers, J. E. (2005) The relationships among liking, love, and wellness: Implications for college student romances. Manuscript submitted for publication.

[155] Sinclair, S. L., \& Myers, J. E. (2004) Weighty issues: The relationship between objectified body consciousness and wellness in a group of college women. Journal of College Counseling, 7(2), 151-160.

[156] Stallings, W. M. (1969) The predictive validity of the Torrence Figural Test (Form B) of Creative Thinking in the college of fine and applied arts (Office of Education Rep. No. RR-309). Washington, D.C.: Office of Education.

[157] Soper, B., Kelly, W. E., \& Von Bergen, C. W. (1997) A preliminary study of sleep length and hallucinations in a college student population. College Student Journal, 31(2), 272-275.

[158] Stanca, L. (2006) The Effects of Attendance on Academic Performance: Panel data evidence from Introductory microeconomics, forthcoming. Journal of Economic Education.

[159] Soetevent, A. \& Kooreman, P. (2004) A Discrete Choice Model with Social Interactions; with an Application to High School Teen Behaviour. CCSO Centre for Economic Research, University of Groningen Working Paper.

[160] St. John, E. P., Hu, S., Simmons, A., Carter, D. F., \& Weber, J. (2004) What difference does a major make? The influence of college major field on persistence by African American and White students. Research in Higher Education, 45(3), 209-232.

[161] Struthers, C. W., Perry, R. P., \& Menec, V. H. (2000) An examination of the relationship among academic stress, coping, motivation, and performance in college. Research in Higher Education. 41(5), 581-592.

[162] The College Board. (1999) College Bound Servitors. New York.

[163] The National Parkinson Foundation, Inc. Sleep Self-Evaluation Form. (n.d.). Retrieved February 4, 2004, from

http://www.parkinson.org/qsleep.htm

[164] Thoits, P. A., (1995) Stress, coping, and social support processes: Where are we? What next? Journal of Health and Social Behavior, 35(extra issue), 53-79.

[165] Thomas, P. V. and J. L. Higbee. 2000 The relationship between involvement and success in developmental algebra. Journal of College Reading and Learning 30(2), 222-232. Online accessed at http://www.tandfonline.com/doi/abs/10.1080/10790195.2000.10850 
097?journalCode $=$ ucrl20

See

also

http://www.freepatentsonline.com/article/Journal-College-Reading-Le arning/62924952.html

[166] Thompson, M. E. and B. C. Plummer. (1979) Remedial college freshmen English students: Description and characteristics. Reading Horizons 19(3), 248-255.

[167] Tiffany, C. and Cary, J. J. (2008) Impact of attendance policies on course attendance among college students. Journal of the Scholarship of Teaching and Learning, 8 (3), 29-35.

[168] Trockel, M.T., Barnes, M.D., \& Egget, D.L. (2000) Health-related variables and academic performance among first-year college students: Implications for sleep and other behaviors. Journal of American College Health, 49, 125-131.

[169] Tinto, V. (1987b) Leaving College: Rethinking the causes and cures of student attrition. Chicago: The University of Chicago Press.

[170] Tinto, V. (1993) Leaving College: Rethinking the causes and cures of student attrition (2nd ed.). Chicago: The University of Chicago Press.

[171] Tinto, V. \& Goodsell, A. (1993) A longitudinal study of freshman interest groups at the University of Washington. University Park, PA: National Center on Postsecondary Teaching, Learning, and Assessment. (ERIC Document Reproduction Service No. ED368269).

[172] Trockel, M. T., Barnes, M. D., \& Egget, D. L. (2000) Health-related variables and academic performance among first-year college students: Implications for sleep and other behaviors. Journal of American College Health, 49(3), 125-131.

[173] Turbow, T. Y. (1985) The relationship of exercise to academic achievement and sense of well being among college students. Dissertation Abstracts International, 46(6A), 1538-1539.

[174] UBel (2002) E-Learning (unpublished paper), University of Botswana, Gaborone.

[175] UNAIDS (2006) Joint United Nations Programme on HIV/AIDS. Uniting the World against AIDS report. Available at: http://www.unaids.org Retrieved on May, 23, 2006.

[176] Urban-Lurain, M, \& Weinbank, D.J. (2000) Attendance and outcome in a large collaborative learning performance assessment course. Paper presented at the annual meeting of the American Educational Research Association (AEIRA). U. S. Department of Education.

[177] Van Blerkon, M.L. (1992) Class attendance in undergraduate courses. The Journal of Psychology, 126, (5), 487-494.

[178] Vickers, K. S., Patten, C. A., Lane, K., Clark, M. M., Croghan, I. T., \& Schroeder, D. R., et al. (2003) Depressed versus non-depressed young adult tobacco users: Differences in coping style, weight concerns, and exercise level. Health Psychology, 22(5), 498-503.

[179] Wang, A., Chen, L., Zhao, B., \& Xu, Y. (2006) First-year students' 
psychological and behavior adaptation to college: The role of coping strategies and social support. US- China Education Review, 3(5), 51-57.

[180] Webb, W. B. (1982) Biological rhythms, sleep and performance. Chichester, England: Wiley.

[181] Wiggins, G. (1998) Educative assessment Designing assessments to inform and improve student performance. San Francisco: Jossey-Bass.

[182] Wilson G. S., Pritchard M. E., \& Schaffer J. (2004) Athletic status and drinking behavior in college students: The influence of gender and coping styles. Journal of American College Health, 52(6), 269-273.

[183] Young, J. R.( 2002, December 6) Homework? What homework? The Chronicle of Higher Education, pp. A35-A37.

[184] Zajacova, A., Lynch, S. M., \& Espenshade, T. J. (2005) Self-efficacy, stress, and academic success in college. Research in Higher Education, 46(6), 677-706.

[185] Zhang, Z., \& RiCharde, R., S., (1998, May) Prediction and analysis of freshman retention. Paper presented at the annual forum of the Association for Institution Research, Minneapolis, MN.

[186] Zubernis, L., \& Snyder, M. (2007) Considerations of additional stressors and developmental issues for gay, lesbian, bisexual, and transgender college students. Journal of College Student Psychotherapy, 22(1), 75-79. 